\title{
PERLAKUAN AKUNTANSI PENDAPATAN DAN PENYAJIAN LAPORAN KEUANGAN BERDASARKAN PSAK NO.23 PADA PT. REDMEN ENERGI DANICA
}

\author{
Winda ${ }^{1}$ \\ ${ }^{1)}$ Program Studi Akuntasi, Fakultas Ekonomi Universitas Krisnadwipayana \\ Kampus Unkris Jatiwaringin \\ email:anggra.wnd@gmail.com \\ Mulia Rahmah ${ }^{2}$ ) \\ ${ }^{2}$ Program Studi Akuntasi, Fakultas Ekonomi Universitas Krisnadwipayana \\ Kampus Unkris Jatiwaringin \\ email:muliarahmah@gmail.com
}

\begin{abstract}
This research was conducted to find out how the Accounting Treatment of Income and Presentation of Financial Statements in accordance with Financial Accounting Standards No. 23 of 2015. The study was conducted at PT Redmen Energi Danica, which is domiciled on Jalan Pejaten Raya No $5 E$ Pejaten Barat Pasar Minggu South Jakarta 12510. The method used for data collection is descriptive qualitative, the data used are obtained from observation, interviews and company documentation. financial data. The results showed that the Danica Energy Reduction Unit during applying the cash basis method in revenue recognition, ie revenue recognized when payments received from customers or cash received. The accounting treatment for the presentation and presentation of the financial statements of PT Redmen Energi Danica is not in accordance with the Statement of Financial Accounting Standards (PSAK) No. 23 of 2015, namely income recognized under the accrual basis method.
\end{abstract}

Keywords: Accounting For Income, Presentation Of Financial Statement, PSAK NO. 23

\section{PENDAHULUAN}

Tujuan di dirikannya sebuah perusahaan pada umumnya adalah untuk meningkatkan dan memperoleh keuntungan pada tingkat tertentu. Pertumbuhan perusahaan dimasa depan menjadi harapan yang diinginkan oleh pihak internal maupun eksternal perusahaan. Salah satu cara yang dapat dilakukan untuk mengetahui kondisi perusahaan di masa yang akan dating adalah melalui nilai pendapatan dalam suatu periodic. Untuk memudahkan perusahaan memperoleh informasi berkaitan dengan pendapatan, maka diperlukan pemberian kepastian informasi yang menyajikan laporan keuangan secara akurat yaitu Akuntansi.

Pendapatan merupakan hal yang sangat berkaitan dengan kegiatan operasional perusahaan, pendapatan yang disajikan dalam laporan keuangan harus mencerminkan pendapatan yang diterima oleh perusahaan pada periode tertentu. Untuk dapat memperoleh informasi laba yang akurat, maka arus pendapatan harus diterapkan dengan baik yaitu sesuai dengan prinsip akuntansi.Dalam konsep pendapatan permasalahan utamanya adalah menentukan saat pengakuan pendapatan, jika penerapan pendapatan sesuai Standar Akuntansi Keuangan maka pendapatan yang diterapkan dapat dikatakan wajar. Pada umumnya perusahaan mengakui pendapatan pada saat direalisasikan dan dihasilkan, pendapatan ini sangat berpengaruh pada besarnya pendapatan yang akan disajikan dalam laporan keuangan yang diperoleh dalam suatu periode.

Dasar akuntansi yang digunakan dalam perhitungan hasil usaha (laba/rugi) periodic dan penentuan posisi keuangan dilakukan dengan metodeakrual. Pembukuan yang dilakukan tidak hanya sekedar pencatatan transaksi penerimaan dan pengeluaran kas, akan tetapi juga pencatatan terhadap setiap perubahan aktiva dan kewajiban, demikian pula pendapatan dan biaya pada saat terjadinya atau diakuinya perubahan yang dimaksud. Sumber pendapatan merupakan penghasilan yang diperoleh dari kegiatan operasional, sumber pendapatan bagi perusahaan sangat berguna 
Printed ISSN 2406-7415

e-ISSN 2655-9919

Jurnal Akuntansi \& Bisnis Krisnadwipayana

Vol. 6 No. 2 (Mei - Agustus) 2019

karena dengan sumber pendapatan yang diperoleh perusahaan dapat digunakan untuk melaksanakan kegiatan perusahaan dan juga merupakan faktor yang menentukan kelangsungan hidup perusahaan sehingga perusahaan dapat mencapai tujuannya dan menutup pengeluaran perusahaan dalam suatu periode.

Aktivitas PT Redmen Energi Danica sebagai mana tertuang didalam perizinan usahanya adalah perdagangan barang dan jasa mekanikal, elektrikal dan perlengkapan lainnya. Pendapatan yang diperoleh PT Redmen Energi Danica dari penjualan barang dan jasa, pada saat penjualan barang dan jasa tersebut maka diperoleh pendapatan. Cara pembayaran yang diberlakukan kepada pelanggan yaitu dengan cara tunai dan kredit. Pengakuan pendapatan pada PT Redmen Energi Danica, belum sesuai dengan Standar Akuntansi Keuangan. Karena pendapatan yang diakui oleh perusahaan yaitu pada saat kas diterima bukan pada saat tanggal terjadinya transaksi. Sedangkan menurut PSAK No. 23 pendapatan diakui pada saat barang atau jasa diberikan walaupun kas belum diterima (accrual basis), hal ini mengakibatkan adanya pendapatan yang belum diakui pada periode tertentu. Hal ini akan mengakibatkan kerugian pada perusahaan misalnya pada saat pengajuan pinjaman ke Bank, karena Bank akan menyetujui pinjaman tersebut jika laporan keuangan perusahaan telah sesuai dengan Standar Akuntansi Keuangan.

Berdasarkanlatarbelakangdiatas, penulis tertarik melakukan penelitian untuk dibahas secara terperinci dengan judul

"Perlakuan Akuntansi Pendapatan Dan Penyajian Laporan Keuangan Berdasarkan PSAK No. 23 Pada PT Redmen Energi Danica"

\section{TINJAUAN PUSTAKA}

\section{Pengertian Akuntansi}

Definisi akuntansi seperti yang diberikan oleh komite dari American Institute Of Certified Public Accounting (AICPA) dalam Harahap (2015) adalah sebagai berikut :

"Akuntansi adalah suatu seni pencatatan, penggolongan,

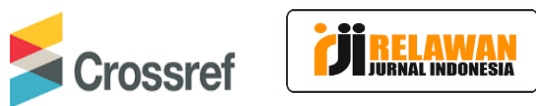

dan pengikhtisaran dengan

cara tertentu dan dalam

ukuran moneter, transaksi

dan kejadian kejadian yang

umumnya bersifat keuangan

dan termasuk menafsirkan

hasil-hasilnya."

\section{Pendapatan}

Dalam Pernyataan Standar Akuntansi

Keuangan (PSAK) No.23(2015:07) menjelaskan bahwa :

"Pendapatan adalah arus masuk bruto dari manfaat ekonomik yang timbul dari aktivitas normal entitas selama suatu periode jika arus masuk tersebut mengakibatkan kenaikan ekuitas yang tidak berasal dari dari konstribusi penanam modal".

\section{Pengakuan Pendapatan}

Permasalahan utama dalam akuntansi untuk pendapatan adalah menentukan pengakuan pendapatan. Kadang-kadang terdapat penyerahan barang atau jasa yang menghasilkan pendapatan pada saat yang sama dan ada kalanya penyerahan barang dan jasa dilakukan terlebih dahulu sedangkan imbalannya atau pendapatannya diterima kemudian. Maka disini timbul suatu masalah yang berkaitan dengan kapan suatu pendapatan itu diakui dan dicatat besarnya.

Belkoui (2007: 16) menyatakan bahwa ada dua metode pengakuan pendapatan dalam periode akuntansi, yaitu :

1. Dasar Akrual (Accrual Basis) Pada dasar akrual ini pengakuan pendapatan dapat mengimplikasikan bahwa pendapatan sebaiknya dilaporkan selama produksi, pada akhir produksi, pada saat penjualan produk atau pada saat penagihan penjualan. Pendapatan diakui pada periode terjadinya transaksi pendapatan. Jadi dalam transaksi penjualan atau penyerahan barang dan jasa yang dilakukan walaupun kas belum diterima, maka transaksi tersebut sudah dicatat dan diakui sebagai pendapatan perusahaan.

2. Dasar kejadian penting (Critical Event Basis/Cash Basis) Pengakuan pendapatan dipicu oleh kejadian penting dalam siklus operasi. Cash Basis atau dasar tunai adalah 
Printed ISSN 2406-7415

e-ISSN 2655-9919

Jurnal Akuntansi \& Bisnis Krisnadwipayana

Vol. 6 No. 2 (Mei - Agustus) 2019

apabila pendapatan dan beban hanya diperhitungkan berdasarkan penerimaan dan pengeluaran kas. Ini berarti dengan penggunaan dasar tunai atau cash basis yang murni (pure basis), penda

\section{Sumber Pendapatan}

Dalam Pernyataan Standar Akuntansi Keuangan (PSAK) No. 23 (2015:01) Pernyataan ini harus diterapkan dalam akuntansi pendapatan yang timbul dari transaksi dan kejadian antara lain: Penjualan barang, Penjualan jasa, dan Penggunaaan aset entitas oleh pihak lain yang menghasilkan bunga, royalti dan deviden

\section{Laporan Keuangan}

Laporan keuangan adalah hasil dari proses akuntansi yang menyajikan informasi keuangan perusahaan yang dapat memenuhi kebutuhan umum para pemakainya. Laporan keuangan harus disajikan dengan cara-cara dan prosedur tertentu beradasarkan aturan yang berlaku, jadi laporan keuangan perusahaan akan terjadi kesalahan apabila tidak mengikuti aturan tersebut. Penyelenggaraan sistem catatan akuntansi harus mencakup aktivitas keseluruhan yang dibutuhkan untuk memeberikan keseluruhan informasi yang dapat digunakan untuk perencanaan, pengendalian dan pelaporan keadaan keuangan perusahaan.

Tujuan Laporan Keuangan

Untuk memenuhi kebutuhan perusahaan laporan keuangan disusun dan disajikan sekurang-kurangnya setahun sekali. Perusahaan sebagai pengguna laporan keuangan memerlukan dan berhak untuk memperoleh informasi tambahan disamping yang tercakup dalam laporan keuangan. Perusahaan sangat bergantung pada laporan keuangan sebagai sumber utama informasi keuangan atas usaha yang dijalankan karena laporan keuangan tersebut disusun dan disajikan dengan mempertimbangkan kebutuhan pengguna yang selanjutnya bisa bermanfaat dan digunakan sebagai dasar pemikiran suatu keputusan akan kelangsungan hidup perusahaan.

\section{Jenis-jenis Laporan Keuangan}

Komponen laporan keuangan lengkap menurut Pernyataan Standar Akuntansi Keuangan (PSAK) No. 1 (2015:1.3) terdiri dari :
1. Laporan posisi keuangan pada akhir periode

2. Laporan laba rugi dan penghasilan komprehensif lain selama periode

3. Laporan perubahan ekuitas selama periode

4. Laporan arus kas selama periode

5. Catatan atas laporan keuangan, berisi ringkasan kebijakan akuntansi yang signifikan dari informasi penjelasan lain

6. Laporan posisi keuangan pada awal periode terdekat sebelumnya ketika entitas menerapkan suatu kebijakan akuntansi secara retrospektif atau membuat penyajian kembali pos-pos laporan keuangan.

\section{Laporan Laba Rugi}

Laporan laba rugi adalah laporan yang menunjukan kemampuan perusahaan dalam menghasilkan laba, yang digambarkan dari selisih antara pendapatan dan beban usaha pada suatu periode tertentu.

\section{METODE PENELITIAN}

Salah satu perusahaan swasta yang menjadi objek penelitian adalah PT Redmen Energi Danica, yang berdomisili di JalanPejaten Raya No 5E Pejaten Barat PasarMinggu Jakarta Selatan 12510. Adapun waktu penelitian secara keseluruhan dilaksanakan pada bulan Januari 2018 sampai dengan September 2018. Populasi dan sampel dalam penelitian ini adalah laporan keuangan dari PT Redmen Energi Danica Tahun 2017. Pengumpulan data yang dilakukan untuk melengkapi penelitian ini dengan menggunakan Interview, Observasi, dan Dokumentasi.Metode yang digunakan dalam penelitian ini adalah deskriptif kualitatif dengan mendeskripsikan atau menggambarkan keadaan objek penelitian yang sesungguhnya.

1. Mengumpulkan data perusahaan yang terkait dengan pendapatan, data tersebut berupa bukti kas masuk, purchase order, pencatatan transaksi, prosedur penerimaan kas dan laporan keuangan.

2. Menganalisis purchase order yang diterima apakah telah dicatat dan diakui kedalam bukti kas masuk dan dicatat sesuai prosedur 
Printed ISSN 2406-7415

e-ISSN 2655-9919

Jurnal Akuntansi \& Bisnis Krisnadwipayana

Vol. 6 No. 2 (Mei - Agustus) 2019

penerimaan kas sesuai tanggal purchase order tersebut diterbitkan, Setelah benar metode pencatatannya, kemudian data-data disesuaikan apakah prosedur yang diterapkan perusahaan telahsesuai dengan Standar Akuntansi Keuangan yang berlaku yaitu Pernyataan Standar Akuntansi Keuangan (PSAK) No. 23. Setelah semua data disesuaikan maka dapat ditarik kesimpulan bahwa pengakuan pendapatan dan penyajian laporan keuangan yang diterapkan PT Redmen Energi Danica sesuai atau tidak dengan Pernyataan Standar Akuntansi Keuangan (PSAK).

\section{HASIL DAN PEMBAHASAN}

PT Redmen Energi Danica bergerak dibidang perdagangan besar mesin, peralatan dan alat teknik, mekanikal, elektrikal, konstruksi perlengkapan lainnya. Pekerjaan yang diterima didapatkan dari memasarkan barang dan jasa ke perusahaan-perusahaan baik yang sudah menjadi rekanan maupun belum menjadi rekanan. Proyek yang diterima terlebih dahulu melakukan proses tender. Barang dan jasa yang diperdagangkan adalah genset, air compressor, diesel engine, jasa instalasi, fabrikasi dan sewa genset. Pekerjaan yang dilaksanakan berdasarkan time schedule yang telah disepakati dalam Kontrak Kerja. Semua pekerjaan harus diselesaikan sesuai dengan Kontrak Kerja dengan demikian pekerjaan dapat mencapai hasil yang baik.

Prosedur dan kebijakan perusahaan menetapkan aturan-aturan mengenai kegiatan dan perilaku sebagai panduan dalam menjalankan tugas dan tanggung jawab setiap karyawan, prosedur dan kebijakan perusahaan disusun untuk menertibkan dan memudahkan dalam menjalankan pekerjaan. Manfaat kebijakan perusahaan sangat penting bagi perusahaan karena ketika kebijakan tersebut dijalankan dengan baik hal tersebut akan meningkatkan nilai tambah bagi perusahaan, melindungi kepentingan perusahaan dan menentukan arah prestasi perusahaan.

Berikut adalah prosedur yang diterapkan di PT Redmen Energi Danica:

1. Prosedur Sales

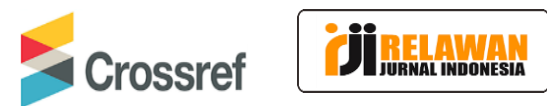

Untuk menjalan tugas sebagai seorang sales berikut adalah prosedur sales:

a. Sales memperkenalkan PT Redmen Energi Danica ke calon pelangganmelaui email, telepon dan datang langsung ke pelanggan dengan melampirkan company profil maksimal 5 pelanggan perminggu.

b. Jika Pelanggan berminat untuk bekerjasama dengan PT Redmen Energi Danica dengan mengirimkan permintaan barang.

c. Setelah permintaan harga diterima sales akan meneruskan permintaan tersebut kepada bagian pembelian dan setelah harga beli didapatkan sales akan menghitung margin dan menerbitkan penawaran harga untuk dikirimkan kepada pelanggan.

d. Setelah penawaran harga disetujui oleh pelanggan, pelanggan akan mengirimkan Purchase Order sebagai bukti bahwa telah terjadi kesepakatan antara pelanggan dengan PT Redmen Energi Danica.

e. PT Redmen Energi Danica akan mengirimkan invoice kepada pelanggan untuk pembayaran pembelian sesuai dengan kesepakatan.

f. Pelanggan akan membayar pembelian tersebut dan barang akan dikirimkan kepada pelanggan.

2. Prosedur Penagihan Kepada Pelanggan

a. Sales Mengajukan pembuatan invoice dan faktur pajak ke bagian keuangan dengan mengisi form pengajuan pembayaran dan melampirkan purchase order dari pelanggan.

b. Bagian keuangan akan mengecek dokumen pengajuan yang diajukan oleh sales.

c. Jika dokumen sudah benar bagian keuangan akan menerbitkan invoice dan faktur pajak.

d. Pembayaran kepada PT Redmen Energi Danica melalui transfer ke Bank Mandiri atau BCA.

e. Setelah transfer pelanggan wajib mengirimkan konfirmasi kepada PT 
Printed ISSN 2406-7415

e-ISSN 2655-9919

Jurnal Akuntansi \& Bisnis Krisnadwipayana

Vol. 6 No. 2 (Mei - Agustus) 2019

Redmen Energi Danica dengan mengirimkan bukti transfer melalui email atau telepon.

Hasil Penelitian

Macam-macam Pendapatan PT

Redmen Energi Danica

\begin{tabular}{|c|c|c|c|c|}
\hline $\begin{array}{l}\mathrm{N} \\
\mathrm{o} .\end{array}$ & $\begin{array}{l}\text { Perusahaa } \\
\mathrm{n}\end{array}$ & Pekerjaan & $\begin{array}{l}\text { Tahu } \\
\mathrm{n}\end{array}$ & Nilai \\
\hline 1 & $\begin{array}{l}\text { PT } \\
\text { Falkonet } \\
\text { Kontrol } \\
\text { Elektrika }\end{array}$ & $\begin{array}{l}\text { Pengadaa } \\
\text { n Actuator } \\
\text { Pneumatic } \\
\text { Nobro }\end{array}$ & 2016 & Rp.38.500.000 \\
\hline 2 & $\begin{array}{l}\text { PT Atlas } \\
\text { Copco } \\
\text { Nusantara }\end{array}$ & $\begin{array}{l}\text { Pengadaa } \\
\mathrm{n} \\
\text { Radiator, } \\
\text { Shround } \\
\text { Fan }\end{array}$ & 2016 & Rp.5.516.500 \\
\hline 3 & $\begin{array}{l}\text { PT } \\
\text { Madhani } \\
\text { Talatah } \\
\text { Nusantara }\end{array}$ & $\begin{array}{l}\text { Pengadaa } \\
\text { n Lincoln } \\
\text { Grease }\end{array}$ & 2017 & Rp.17.800.000 \\
\hline 4 & $\begin{array}{l}\text { PT Atlas } \\
\text { Copco } \\
\text { Nusantara }\end{array}$ & $\begin{array}{l}\text { Pengadaa } \\
\text { n Rack } \\
\text { Steel For } \\
\text { LV NHM }\end{array}$ & 2017 & Rp.28.497.150 \\
\hline 5 & $\begin{array}{l}\text { PT } \\
\text { Stanindo } \\
\text { Artha } \\
\text { Langgeng }\end{array}$ & $\begin{array}{l}\text { Pengadaa } \\
\text { n Spare } \\
\text { Part } \\
\text { Baldor }\end{array}$ & 2017 & Rp.237.313.000 \\
\hline 6 & $\begin{array}{l}\text { PT Bosch } \\
\text { Rexroth }\end{array}$ & $\begin{array}{l}\text { Pengadaa } \\
\text { n Cortec } \\
\text { VpCI- } 416\end{array}$ & 2017 & Rp.17,720.000 \\
\hline 7 & $\begin{array}{l}\text { PT Multi } \\
\text { Guna } \\
\text { Equipmen } \\
\text { t }\end{array}$ & $\begin{array}{l}\text { Pengadaa } \\
\text { n Dan } \\
\text { Instalasi } \\
\text { New } \\
\text { Engine } \\
\text { Deutz }\end{array}$ & 2017 & Rp.770.000.000 \\
\hline
\end{tabular}

Pendapatan PT Redmen Energi Danica diakui berdasarkan metode cash basis yaitu mengakui pendapatan yang hanya diperhitungkan berdasarkan penerimaan kas. Dan penjualan barang atau jasa hanya dapat diperhitungkan pada saat tagihan pelanggan diterima.

Pada saat terjadinya penerimaan kas atas penjualan barang dan jasa, perusahaan melakukan pencatatan yaitu dengan menjurnal. Pada saat perusahaan mengajukan tagihan kepada pelanggan atas penjualan barang dan jasa, perusahaan tidak melakukan pencatatan.

\section{Pembahasan}


Printed ISSN 2406-7415

e-ISSN 2655-9919

Jurnal Akuntansi \& Bisnis Krisnadwipayana

Vol. 6 No. 2 (Mei - Agustus) 2019

\section{Jurnal Pencatatan Transaksi Penjualan Barang \\ Sumber : Diolah Penulis,(2018)}

Dalam PSAK No.23 pendapatan diakui berdasarkan metode accrual basis yaitu pendapatan diakui pada saat periode terjadinya transaksi pendapatan. Dengan dasar ini, pengaruh transaksi dan peristiwa lain diakui pada saat kejadian walaupun kas belum diterima. Dari transaksi diatas, seharusnya perusahaan melakukan pencatatan dengan jurnal sebagai berikut:

\section{Tabel II}

Jurnal Pencatatan Transaksi Penjualan

Barang

Versi PSAK No.23

\begin{tabular}{|c|c|c|c|}
\hline $\begin{array}{l}\text { Jurnal } \\
\text { Pencatatan }\end{array}$ & $\begin{array}{l}\text { Debet } \\
\text { Rp }\end{array}$ & $\begin{array}{l}\text { Kredit } \\
\text { Rp }\end{array}$ & $\begin{array}{l}\text { Keteranga } \\
\text { n }\end{array}$ \\
\hline $\begin{array}{l}\text { Piutang } \\
\text { Pendapatan } \\
\text { PPN }\end{array}$ & $\begin{array}{l}6.490 .00 \\
0\end{array}$ & $\begin{array}{l}5.900 .00 \\
0 \\
590.000\end{array}$ & $\begin{array}{l}\text { Pencatatan } \\
\text { pada saat } \\
\text { invoice } \\
\text { dikeluarkan } \\
2 \text { Oktober } \\
2016\end{array}$ \\
\hline Piutang & $\begin{array}{l}6.490 .00 \\
0\end{array}$ & $\begin{array}{l}6.490 .00 \\
0\end{array}$ & $\begin{array}{l}\text { Pencatatan } \\
\text { pada saat } \\
\text { penerimaan } \\
\text { kas } 1 \\
\text { November } \\
2016\end{array}$ \\
\hline
\end{tabular}

Pada tanggal 5 Desember 2016 PT Redmen Energi Danica mendapatkan purchase order atas pembelian tunai 2 unit Actuator dari PT Flakonet Kontrol Elektrika dan menerbitakan tagihan dengan nomr 099/INV/FKE/XII/2016 Rp.38.500.000dan PPN 10\% Rp. 3.850.000. Kemudian PT Flakonet Kontrol Elektrika melakukan pembayaran pada tanggal 5 Desember 2016 sebesar Rp. 42.350.000. Dari transaski diatas pada tanggal 5 Desember 2016 perusahaan melakukan pencatatan dengan jurnal sebagai berikut:

\section{Tabel III}

\section{Jurnal Pencatatan Transaksi PenjualanBarang}

Sumber : Diolah Penulis,(2018)
Dalam PSAK No.23 pendapatan diakui berdasarkan metode accrual basis yaitu

\begin{tabular}{|l|l|l|l|}
\hline $\begin{array}{l}\text { Jurnal } \\
\text { Pencatatan }\end{array}$ & Debet Rp & Kredit Rp & Keterangan \\
\hline Kas & 6.490 .000 & & $\begin{array}{l}\text { Pencatatan } \\
\text { pada saat } \\
\text { penerimaan } \\
\text { pendapatan }\end{array}$ \\
& & 6.490 .000 & $\begin{array}{l}\text { November } \\
2016\end{array}$ \\
\hline
\end{tabular}

pendapatan diakui pada saat periode terjadinya transaksi pendapatan. Dengan dasar ini, pengaruh transaksi dan peristiwa lain diakui pada saat kejadian walaupun kas belum diterima, karena pada transaksi diatas adalah penjualan tunai dimana transaksi dan pembayaran terjadi ditanggal yang sama maka pencatatan telah sesuai dengan PSAK No. 23.

2. Pendapatan Instalasi

Pendapatan instalasi PT Redmen Energi Danica adalah pendapatan yang bersumber dari penagihan invoice kepada pelanggan atas pekerjaan jasa instalasi genset dan instalasi engine. PT Redmen Energi Danica mengakui pendapatan instalasinya dengan menggunakan metode cash basis dimana pendapatan diakui pada saat kas diterima. Pada tanggal 21 Desember 2017 PT Redmen Energi Danica mendapatkanpurchase order dari PT Multi Guna Equipment dan menerbitakan tagihan dengan nomr 110/INV/MGE/XII Rp.770.000.000dan PPN $10 \%$ Rp. 77.000.000. Kesepakatan pembayaran untuk purchase order tersebut adalah $100 \%$ setelah pekerjaan selesai dimana waktu pekerjaan tersebut adalah 1 minggu. Kemudian PT Multi Guna Equipment melakukan pembayaran pada tanggal 28 Desember 2017.

Dari transaski diatas pada tanggal 21 Desember 2017 perusahaan tidak melakukan pencatatan. Namun pada tanggal 28 Juni 2017, perusahaan melakukan pencatatan dengan jurnal sebagai berikut:

\section{Tabel IV}

Jurnal Pencatatan Transaksi Pendapatan Instalasi Versi Perusahaan Sumber : Diolah Penulis,(2018) 
Printed ISSN 2406-7415

e-ISSN 2655-9919

Jurnal Akuntansi \& Bisnis Krisnadwipayana

Vol. 6 No. 2 (Mei - Agustus) 2019

Dalam PSAK No.23 pendapatan diakui berdasarkan metode accrual basis yaitu pendapatan diakui pada saat periode terjadinya transaksi pendapatan. Dengan dasar ini, pengaruh transaksi dan peristiwa lain diakui pada saat kejadian walaupun kas belum diterima. Dari transaksi diatas, seharusnya perusahaan

\begin{tabular}{|c|c|c|c|}
\hline $\begin{array}{l}\text { Jurnal } \\
\text { Pencatata } \\
\text { n }\end{array}$ & Debet Rp & Kredit Rp & Keterangan \\
\hline $\begin{array}{l}\text { Kas } \\
\text { Pendapata } \\
\text { n }\end{array}$ & 847.000 .000 & 847.000 .000 & $\begin{array}{l}\text { Pencatatan } \\
\text { pada saat } \\
\text { penerimaan } \\
\text { kas } 28 \\
\text { Desember } \\
2018\end{array}$ \\
\hline
\end{tabular}

melakukan pencatatan dengan jurnal sebagai berikut:

Tabel V

Jurnal Pencatatan Transaksi Pendapatan Instalasi Versi PSAK No.23

\begin{tabular}{|c|c|c|c|}
\hline $\begin{array}{l}\text { Jurnal } \\
\text { Pencatata } \\
\text { n }\end{array}$ & Debet $R p$ & Kredit Rp & Keterangan \\
\hline $\begin{array}{l}\text { Piutang } \\
\text { Pendapatan } \\
\text { PPN }\end{array}$ & 847.000 .000 & $\begin{array}{l}770.000 .000 \\
77.000 .000\end{array}$ & $\begin{array}{l}\text { Pencatatan } \\
\text { pada saat } \\
\text { invoice } \\
\text { dikeluarkan } \\
21 \text { Desember } \\
2017 \\
\end{array}$ \\
\hline $\begin{array}{l}\text { Kas } \\
\text { Piutang }\end{array}$ & 847.000 .000 & 847.000 .000 & $\begin{array}{l}\text { Pencatatan } \\
\text { pada saat } \\
\text { penerimaan } \\
\text { kas 28 } \\
\text { Desember } \\
2017\end{array}$ \\
\hline
\end{tabular}

3. Pendapatan Sewa

Pendapatan sewa PT Redmen Energi Danica adalah pendapatan yang bersumber dari penagihan invoice kepada pelanggan atas jasa sewa genset. PT Redmen Energi Danica mengakui pendapatan sewanya dengan menggunakan metode cash basis dimana pendapatan diakui pada saat kas diterima.

Pada tanggal 8 Maret 2018PT Redmen Energi Danica mendapatkan purchase order dari PT Madhani Talatah Nusantara dan menerbitkan tagihan dengan nomor 020/INV/MTN/III/2017 sebesar Rp. 17.800.000 dan PPN 10\% Rp. 1.780.000, Kesepakatan pembayaran untuk purchase

\begin{tabular}{|c|c|c|c|}
\hline $\begin{array}{l}\text { Jurnal } \\
\text { Pencatat } \\
\text { an }\end{array}$ & Debet Rp & Kredit Rp & Keterangan \\
\hline $\begin{array}{l}\text { Piutang } \\
\text { Pendapat } \\
\text { an } \\
\text { PPN }\end{array}$ & 19.580 .000 & $\begin{array}{l}17.800 .000 \\
1.780 .000\end{array}$ & $\begin{array}{lr}\text { Pencatatan pada } \\
\text { saat invoice } \\
\text { dikeluarkan } \\
\text { Maret } 2017\end{array}$ \\
\hline $\begin{array}{l}\text { Kas } \\
\text { Piutang }\end{array}$ & 19.580 .000 & 19.580 .000 & $\begin{array}{l}\text { Pencatatan pada } \\
\text { saat penerimaan } \\
\text { kas } 7 \text { Mei } 2017\end{array}$ \\
\hline
\end{tabular}

Jurnal Pencatatan Transaksi Pendapatan Sewa Versi Perusahaan Sumber : Diolah Penulis,(2018)

Dalam PSAK No.23 pendapatan diakui berdasarkan metode accrual basis yaitu pendapatan diakui pada saat periode terjadinya transaksi pendapatan. Dengan dasar ini, pengaruh transaksi dan peristiwa lain diakui pada saat kejadian walaupun kas belum diterima. Dari contoh di atas, seharusnya perusahaan melakukan pencatatan dengan jurnal sebagai berikut:

Tabel VII

Jurnal Pencatatan Transaksi Pendapatan Sewa Versi PSAK No.23 
Printed ISSN 2406-7415

e-ISSN 2655-9919

Jurnal Akuntansi \& Bisnis Krisnadwipayana

Vol. 6 No. 2 (Mei - Agustus) 2019

Sumber : Diolah Penulis,(2018)

\section{Penyajian Dan Pengungkapan}

Berdasarkan data yang ditampilkan pada tabel I sampai VII, pendapatan adalah arus kas masuk bruto dari manfaat ekonomi yang timbul dari manfaat ekonomi yang timbul dari aktivitas normal entitas selama suatu periode. Pengakuan pendapatan pada PT Redmen Energi Danica untuk pendapatan atas barang, pendapatan sewa dan pendapatan instalasi dapat dikatakan belum sesuai dengan Pernyataan Standar Akuntansi Keuangan (PSAK) No. 23 karena pendapatan diakui pada saat kas atau pembayaran diterima (cash basis). Sedangkan dalam PSAK No.23 pendapatan diakui berdasarkan metode accrual basis yaitu pendapatan diakui pada saat periode terjadinya transaksi pendapatan. Dengan dasar ini, pengaruh transaksi dan peristiwa lain diakui pada saat kejadian walaupun kas belum diterima.

Metode pengakuan pendapatan yang diterapkan oleh PT Redmen Energi Danicaadalah metode cash basis yaitu mengakui pendapatan yang hanya diperhitungkan berdasarkan penerimaan kas, dan penjualan barang atau jasa hanya dapat diperhitungkan pada saat tagihan diterima dari pelanggan. Didalam laporan keuangan PT Redmen Energi Danica terdapat laporan laba rugi yang dapat menunjukan kemampuan perusahaan dalam menghasilkan laba yang dihasilkan dari pendapatan perusahaan pada suatu periode. Laba yang diperoleh tersebut akan menjadi parameter perusahaan untuk periode berikutnya.

Dengan menggunakan metode cash basis dalam mengakui pendapatan yang diterapkan pada PT Redmen Energi Danica, dimana pendapatan tersebut diakui pada saat pemyaran diterima dari pelanggan atau kas diterima, hal ini akan menyebabkan pendapatan yang seharusnya menjadi periode saat ini diakui sebagai pendapatan saat kas diterima.

\section{KESIMPULAN DAN SARAN Kesimpulan}

Dari hasil penelitian ini, maka penulis akan menarik kesimpulan, antara lain sebagai berikut : 1. PT Redmen Energi Danica selama ini menerapkan metode cash basis dalam pengakuan pendapatan yaitu pendapatan diakui pada saat pembayaran diterima dari pelanggan atau kas diterima.

2. Perlakuan akuntansi pendapatan dan penyajian laporan keuangan PT Redmen Energi Danica belum sesuai dengan Pernyataan Standar Akuntansi Keuangan (PSAK) No. 23 Tahun 2015 yaitu pendapatan diakui dengan metode accrual basis.

\section{Saran}

Berdasarkan penulisan skripsi ini yang diambil dari data yang telah diperoleh dari perusahaan,maka penulis menyampaikan saran untuk perusahaan sebagai berikut :

1. Sebaiknya Metode yang digunakan dalam pengakuan pendapatan adalah accrual basis, karena telah sesuai dengan Pernyataan Standar Akuntansi (PSAK) No. 23. Pencatatan pengakuan pendapatan berdasarkan cash basis tidak sesuai dengan Standar Akuntansi Keuangan karena pendapatan tidak diakui dalam periode yang seharusnya. Selain itu akan memudahkan perusahaan dalam administrasi ke lembaga-lembaga investor.

2. Sebaiknya PT Redmen Energi Danica membat prosedur untuk menerapkan pengakuan pendapatan sesuai dengan Pernyataan Standar Akuntansi keuangan (PSAK) No. 23 agar dapat tertib dijalankan oleh pihak yang terkait.

3. Sebaiknya PT Redmen Energi Danica mencatat PPN yang diterima terpisah dengan pendapatan.

4. Administrasi akuntansi yang ada saat ini sebaiknya lebih ditingkatkan lagi secara berkelanjutan, sehingga laporan keuangan yang disajikan sesuai sesuai dengan standar atau ketentuan yang berlaku. 
Printed ISSN 2406-7415

e-ISSN 2655-9919

Jurnal Akuntansi \& Bisnis Krisnadwipayana

Vol. 6 No. 2 (Mei - Agustus) 2019

DAFTAR PUSTAKA

Ahmad Syafi'I Syakur, 2015, Intermediate Accounting, Jakarta: A V Publisher

Ahmed Riahi, Belkaoui, 2012, Teori Akuntansi, Edisi Kelima, buku kedua, Jakarta : Salemba Empat

Amin Widjaja Tunggal, 2012, Pengantar Akuntansi Keuangan, Jakarta : Harvarindo,

Dwi Martani, Sylvia Veronica NPS,Ratna Wardani, Aria Farahmita, \& Edward Tanujaya, 2012, Akuntansi Keuangan Menengah Berbasis Psak, Edisi Kesatu, Jakarta : Salemba Empat

Hery, 2015,Pengantar Akuntansi, Jakarta : Grasindo

Hery, SE,M,SI, CRP, RSA, 2017, Analisa Laporan Keuangan Integrated And Comprehensive Edition, Jakarta : Kompas Gramedia

Hery, SE, M,SI, CRP, RSA, CFRM, 2017, Teori Akuntansi Pendekatan Konsep Dan Analisis, Jakarta : Kompas Gramedia

Ikatan Akuntan Indonesia, 2015, Standar Akuntasi Keuangan, Jakarta : IAI

Indra Mahardika Putra SE, AK, M, AK, 2017, Pengantar Akuntansi, Bantul : Quadrant

James M, Reeve, Carl S, Warren, Jonathan E, \& Duchac, 2012, Pengantar Akuntansi Adaptasi Indonesia, Buku 1, Jakarta : Salemba Empat

James M, Reeve, Carl S, Warren, Jonathan E, Duachac, Ersa Tri Wahyuni, Gatot Soepriyanto, Amir Abadi Jusuf, \& Chaerul D, Djakman, 2013, Pengantar Akuntansi Adaptasi Indonesia, Edisi Kesatu, Jakarta : Salemba Empat

Mila Sepliana Setyowati, Tafsir Nurchamid, Retno Kusumastuti, Novita Ikasari, 2016, Pengantar Akuntansi 2, Edisi Pertama, Jakarta : Prenadamedia Group

Mulyadi, 2016, Sistem Akuntansi, Jakarta : Salemba Empat

Nelson Lam \& Peter Lau, 2014, Akuntansi Keuangan Menengah Intermediate Financial Reporting, Edisi Kedua, Jakarta : Salemba Empat

Rudianto, 2012, Pengantar Akuntansi, Jakarta : Erlangga
Sofyan Syafri Harahap, 2015, Teori Akuntansi, Edisi Keempat Belas, Depok : Rajawali Pers

Subarmanyam, 2014, Analisis Laporan Keuangan Financial Statement, Buku 1 Edisi 10, Jakarta : Salemba Empat

Suwardjono, 2014, Teori Akuntansi Perekayasaan Pelaporan Keuangan, Edisi Ketiga, Yogyakarta : BPPFE

Syaiful Bahri, SE, MSA, 2016, Pengantar Akuntansi Berdasarkan SAK ETAP dan IFRS, Jakarta : CV Andi Offset

V, Wiratna Sujarweni, 2017, Analisis Laporan Keuangan, Pustaka Baru Presus 
Printed ISSN 2406-7415

e-ISSN 2655-9919

Jurnal Akuntansi \& Bisnis Krisnadwipayana

Vol. 6 No. 2 (Mei - Agustus) 2019 
Printed ISSN 2406-7415

e-ISSN 2655-9919

Jurnal Akuntansi \& Bisnis Krisnadwipayana

Vol. 6 No. 2 (Mei - Agustus) 2019 